\title{
EL DERECHO DE ACCESO A LA INFORMACIÓN PÚBLICA EN EL MARCO DEL CONSTITUCIONALISMO MULTINIVEL Y DE LA ACTUAL CRISIS SANITARIA.
}

ELOÍSA PÉREZ CONCHILLO 
SUMARIO:

1.- INTRODUCCIÓN. 2.- APROXIMACIÓN AL DERECHO DE ACCESO A LA INFORMACIÓN PÚBLICA EN EL CONTEXTO ACTUAL DE LA CRISIS SANITARIA DEL COVID-19. 3.-BREVE REFERENCIA AL CONSTITUCIONALISMO MULTINIVEL EN EL CONTEXTO ACTUAL.4.-EL DERECHO DE ACCESO A LA INFORMACIÓN PÚBLICA EN EL MARCO DEL CONSTITUCIONALISMO MULTINIVEL. 4.1.a.- El derecho de acceso a la información pública en el Consejo de Europa. 4.1.b.-El derecho de acceso a la información pública en la Unión Europea. 4.2.- Problemas de integración multinivel a propósito del derecho de acceso a la información pública. 5.- CONCLUSIONES. 6.- REFERENCIAS BIBLIOGRÁFICAS. 


\title{
EL DERECHO DE ACCESO A LA INFORMACIÓN PÚBLICA EN EL MARCO DEL CONSTITUCIONALISMO MULTINIVEL Y DE LA ACTUAL CRISIS SANITARIA.
}

\author{
ELOÍSA PÉREZ CONCHILLO ${ }^{1}$ \\ Universidad de Granada
}

\section{INTRODUCCIÓN.}

En este artículo se utilizará el análisis del derecho de acceso a la información pública para plantear una serie de dudas y cuestiones acerca del constitucionalismo multinivel. La elección de este derecho para abordar el trabajo responde principalmente a dos cuestiones. Por un lado, se trata de un derecho sumamente interesante para enriquecer el debate sobre la interpretación de los derechos al adquirir distintos matices en su configuración multinivel. Por otro lado, se trata de una elección realizada a propósito de los tiempos actuales. No es la primera vez que a tenor de las circunstancias políticas y sociales, el derecho de acceso a la información reaparece en el debate público, sugiriendo su reajuste jurídico-constitucional a golpe de acontecimientos. En España, esto ya sucedió a propósito del movimiento 15-M, como consecuencia de la crisis económica de 2008. Tal situación auspició el debate para la aprobación de una norma en España capaz de sosegar el escenario político del momento y hacer frente a la deficiente regulación del derecho de acceso hasta entonces. Así nace la Ley 19/2013, de 9 de diciembre, de transparencia, acceso a la información pública y buen gobierno (LTAIBG), enmarcada en el art. $105 \mathrm{CE}$, y enfocada en colmar las lagunas en materia de transparencia y acceso a la información pública.

1 Master en Justicia Criminal en la Universidad Carlos III de Madrid, Master en Derechos Fundamentales en Perspectiva Nacional, Supranacional y Global en la Universidad de Granada. Actualmente, Profesora Sustituta Interina de Derecho Constitucional en la Universidad de Granada, Doctoranda de Derecho Constitucional. Calle Vista Blanca, 59, 18190, Cenes de la Vega, Granada. Email: eloisapc@ugr.es 
Hoy, la grave crisis sanitaria generada por el COVID-19 ha recordado de nuevo el rol fundamental que ostenta el derecho de acceso a la información pública para la realización del principio de transparencia. Son muchas las cuestiones doctrinales generadas a propósito de esta pandemia global. No obstante, en lo que atañe al derecho objeto de estudio, la crisis sanitaria ha manifestado, por un lado, la vinculación inescindible entre acceso a la información pública y democracia, y por otro, la fragilidad que dicho derecho sigue teniendo en España.

La citada LTAIBG procuró saldar el debate sobre la naturaleza jurídica del acceso a la información, apostando por una visión más bien conservadora en su configuración. No obstante, ser la primera norma expresamente referida en España a la regulación del principio de transparencia y acceso a la información, le dio cierto margen de acomodo para preterir la cuestión de si su encuadre constitucional había sido suficiente y si se ajustaba a los cánones internacionales o no. Por entonces fue suficiente con ese limitado alcance constitucional en tanto que ya era mucho más que nada. Sin embargo, de nuevo hoy parece que la realidad se impone sobre aquella regulación, retomando un debate que lejos de haberse resuelto, revela la necesidad de profundizar sobre el lugar que habría de ocupar el derecho de acceso a la información pública en nuestro país.

En efecto, la excepcionalidad de los acontecimientos sucedidos con la crisis sanitaria ha puesto en jaque la auténtica efectividad de este derecho. Más allá de lo que se creía avanzado en la materia, la crisis del COVID-19 ha reflejado ciertas carencias en torno a la transparencia y acceso a la información. Razón preocupante si se tiene en cuenta el potencial democrático que ostenta el acceso a la información pública en situaciones regidas por la legalidad ordinaria, cuanto más si está vigente el Derecho de excepción ${ }^{2}$.

Será también interesante examinar la relevancia que el derecho de acceso a la información adquiere en el marco internacional. Gracias al desarrollo interpretativo que este derecho ha adquirido en el seno del Consejo de Europa y de la UE, han podido observarse las disidencias en su configuración jurídico-constitucional. Así, podría decirse que en lo relativo al contexto multinivel se ha convertido en un derecho modelo para estudiar la relación y diálogo entre tribunales, y para plantear distintas vías de solución ante la discrepancia interpretativa existente entre ellos.

De tal modo, la relación derecho de acceso a la información pública-constitucionalismo multinivel permitirá plantear nuevos escenarios en la protección de los derechos y discutir cuestiones de encaje entre los distintos ordenamientos. Dicha cuestión será útil no solo a efectos de otorgar el correcto marco de análisis al derecho de acceso a la información, sino también para plantear cuestiones generales que atañen a la integración e interpretación de los derechos en el contexto multinivel.

2 Sobre el desplazamiento del Derecho ordinario cuando se declara alguno de los estados excepcionales previstos en el art. 116 CE y regulados en la L.O 4/1981 de 1 de junio, de los estados de alarma, excepción y sitio se pronunció el TC a propósito de la STC 83/2016, de 28 de abril, FJ 10. 


\section{APROXIMACIÓN AL DERECHO DE ACCESO A LA INFORMACIÓN PÚBLICA EN EL CONTEXTO ACTUAL DE LA CRISIS SANITARIA DEL COVID-19.}

Con ocasión de la pandemia padecida por todos los países del globo, España declaró el estado de alarma al amparo del art. 116 CE. Dicha declaración se efectuó a través del Real Decreto 463/202, de 14 de marzo, por el que se declara el estado de alarma para la gestión de la situación de crisis sanitaria ocasionada por el COVID-19, por el que se adoptaban una serie de medidas dirigidas a «proteger la salud y seguridad de los ciudadanos, contener la progresión de la enfermedad y reforzar el sistema de salud pública» ${ }^{3}$.

La crisis sanitaria del COVID-19, no solo ha puesto en jaque la vida y salud de millones de personas, sino que se ha encargado de poner en marcha mecanismos extraordinarios propios del Derecho Constitucional para enfrentar la situación. A tal efecto, se han aprobado gran cantidad de normas dirigidas a paliar en lo posible las consecuencias negativas de la pandemia ${ }^{4}$, llegándose a limitar derechos fundamentales como medida de contingencia para evitar la propagación del virus ${ }^{5}$.

No son pocas las cuestiones a debatir desde la perspectiva jurídica en lo relativo a la crisis sanitaria ${ }^{6}$. No obstante, centrándonos en la falta de información generalizada

3 Cfr. Preámbulo del Real Decreto 463/2020, de 14 de marzo, por el que se declara el estado de alarma para la gestión de la situación de crisis sanitaria ocasionada por el COVID-19.

4 Puede consultarse toda la normativa aplicable en la gestión del Covid incluyendo las últimas novedades en los Códigos electrónicos sobre el COVID-19 disponibles en el BOE.

5 Dicha limitación, no ha estado exenta de polémica por cuanto ya se han planteado diversas vías para motivar un pronunciamiento constitucional que determine si ha habido una extralimitación del Ejecutivo al haber podido utilizar el estado de alarma de forma impropia, cubriendo en realidad una situación con más encaje en el estado de excepción. Entre tales iniciativas destaca la petición de un grupo de juristas al Defensor del Pueblo para que interponga recurso de inconstitucionalidad y amparo contra el Decreto del estado de alarma por suponer en realidad una suspensión, que no limitación de derechos fundamentales. La noticia puede consultarse entre otros medios en «Un grupo de juristas pide al Defensor del Pueblo que impugne el decreto del estado de alarma por ser «inconstitucional»(19 de abril de 2020). El mundo. La discusión doctrinal respecto a la posible extralimitación del Ejecutivo en la utilización del estado de alarma es extensa. No obstante pueden verse al respecto los interesantes artículos de opinión de ARAGÓN REYES, M. (10 de abril de 2020). «Hay que tomarse la Constitución enserio». El País; DÍAZ REVORIO, F.J. (9 de abril de 2020). «A vueltas con la suspensión de los derechos fundamentales». Almacén de Derecho. En sentido opuesto puede verse entre otros DE LA QUADRASALCEDO, T. (28 de abril de 2020). «La aversión europea al estado de excepción». El País.

6 Así, ha tenido que lidiarse con numerosos frentes abiertos como la grave afección del sistema sanitario ante el colapso de los hospitales, ausencia de presencia unificada de la UE para dar una respuesta coordinada entre los países, falta de coordinación entre Estado y Comunidades Autónomas para recabar los datos. Sobre estas cuestiones pueden consultarse respectivamente, BLANES CLIMENT, M.A. (2020). «Comentarios a la Nota del Portal de Transparencia (17/4/2020): se confirma el apagón informativo sobre el Covid-19 durante el estado de alarma». Blog de Transparencia y Gobierno Abierto — Transparency and Open Government. Y, «Los diferentes criterios con los que se recogen los datos impiden conocer la dimensión de la epidemia en España». (30 de marzo de 2020). Eldiario.es. 
en relación con el foco del problema, el COVID-19, se están planteando numerosos escenarios que apuntan a la categorización del acceso a la información pública como presupuesto básico del actual Estado social y democrático de Derecho.

Hasta el momento no ha sido un derecho que estuviera en el foco del ojo público, ni sobre el que se advirtiera un potencial democrático tan necesario y poderoso como hasta ahora. El acceso a la información pública nunca se había demandado tanto en tan poco tiempo, y esto en mi opinión trae causa de la puesta en práctica de un positivo ejercicio cívico de conciencia. La sociedad ha querido enfrentarse a la pandemia sabiendo, conociendo que debía hacer, cómo debía hacerlo, además de querer someter a escrutinio la gestión pública relativa a la crisis sanitaria en materia de contratación, medidas adoptadas, transparencia, etc.

En este contexto se está cuestionando si se ha dado información suficiente y de calidad a la ciudadanía en las estancias iniciales del virus. Esto es, se discute si un mejor acercamiento al virus, hubiera generado una mayor y más pronta conciencia cívica para tomar decisiones formadas y en este sentido, evitar situaciones que incrementaran el riesgo de contagio ${ }^{7}$. A lo que se añade además, unas políticas comunicativas que en las fases iniciales del virus no se mostraron todo lo determinantes que debieran haber sido, al primar un mensaje de sosiego que trataba evitar el pánico social $^{8}$. En este caso, la interpretación insolidaria de los datos efectuada en los países europeos en las fases preventivas, trasladó el mensaje de que el mayor riesgo se dirigía a concretos sectores sociales vulnerables al virus ${ }^{9}$. De ahí que, el debate público inicial generara un efecto anestésico que retardó la concepción del riesgo para aquellos que quedaban fuera de los grupos identificados como vulnerables. En esta línea, expertos en comunicación han señalado que «respecto de las lecciones previas sobre comunicación institucional, puede extraerse que se incumplieron aspectos relativos a la preparación de la comunidad para el escenario más negativo, se sobreprotegió con un mensaje de calma en etapas iniciales, que supuso luego un choque con la realidad y con la nueva comunicación efectuada» ${ }^{10}$.

\footnotetext{
7 Así lo anticipaba Vid. PRESNO LINERA, M. (2020). «Coronavirus SARS-CoV-2 y derechos fundamentales (3): la emisión y recepción de información». Blog El derecho y el revés. De hecho ha habido diversas denuncias contra miembros del Gobierno pendientes ya de resolución para dirimir en su caso responsabilidades derivadas del posible conocimiento de información y recomendaciones de instancias internacionales como la OMS o el Centro Europeo para el Control y Prevención de Enfermedades que pudieron ser desoídas.

8 Como ha señalado BALAGUER CALLEJÓN, F. (13 de marzo de 2020). «El fracaso de una narrativa insolidaria». El País, «las políticas de comunicación y las narrativas que generan son una parte muy importante del tratamiento de desafíos como el de la crisis sanitaria, que implican a millones de personas en todo el mundo».

9 Vid. BALAGUER CALLEJÓN, F (13 de marzo 2020). «El fracaso de una narrativa...», cit.

10 Cfr. COSTA-SÁNCHEZ, C Y LÓPEZ-GARCÍA, X. (2020). «Comunicación y crisis del coronavirus en España. Primeras lecciones». El profesional de la información, v.29, n 3, p. 10.
} 
Podría decirse que a la pandemia del coronavirus se suma la pandemia de la desinformación ${ }^{11}$. En torno a ésta última debe señalarse que la manipulación informativa y la propagación de bulos han generado un enrarecimiento del debate público, dificultando la distinción entre la información veraz y la falaz ${ }^{12}$. Tan es así que actualmente se ha trasladado al espacio público, el término de «infodemic» que venía utilizando la Organización Mundial de la Salud (OMS) para hacer referencia a la «sobreabundancia de información (alguna rigurosa y otra no) que hace que para las personas sea difícil encontrar recursos fidedignos» ${ }^{13}$. Ahora en el marco de la pandemia, el término «infodemia» llama la atención sobre «la gran cantidad de información que hay sobre el tema, mucha de la cual son bulos o rumores, por lo que vendría a equivaler a una 'epidemia nociva de rumores que se generan durante los brotes' ${ }^{14}$.

Así pues, aunque existen iniciativas para frenar este fenómeno desinformativo mediante la verificación de los datos publicados ${ }^{15}$, la desinformación consigue seguir a la vanguardia. Dato este último que corrobora un reciente estudio realizado por el Reuters Institute de la Universidad de Oxford en el que de los seis países analizados, se muestra que los españoles son los que más responsabilidad atribuyen a los representantes políticos en la difusión de desinformación. De dicho estudio se extrae también que los ciudadanos españoles son los que califican con una puntuación más baja respecto del resto de países analizados, la labor del Gobierno para que los ciudadanos entiendan la pandemia (con un $40 \%$ de puntuación) y las explicaciones que éste ha dado para que la ciudadanía sepa cómo enfrentarse al virus (con un 53\%) ${ }^{16}$.

Esta última cuestión va ligada al problema de la fiabilidad de los datos publicados sobre contabilización de enfermos, ingresados y fallecidos por COVID, dadas las

$11 \mathrm{Al}$ respecto puede verse la interesante nota de prensa «La pandemia se convierte en “infodemia». (19 de abril de 2020). El País.

12 En la misma línea se pronuncian COSTA-SÁNCHEZ, C Y LÓPEZ-GARCÍA, X. (2020). «Comunicación y crisis del coronavirus...», cit., p. 8. Recientemente, sobre noticias falsas puede consultarse MUÑ̃Z-MACHADO CAÑAS, J. (2020). «Noticias falsas. confianza y configuración de la opinión pública en los tiempos de internet». El Cronista del Estado Social y Democrático de Derecho, ejemplar dedicado a Coronavirus y otros problemas, nº. 86-87, págs. 122 a 137.

13 Cfr. Fundéu BBVA, disponible en https://www.fundeu.es/consulta/infodemia/

14 Cfr. Fundéu BBVA, disponible en https://www.fundeu.es/consulta/infodemia/

15 Ha de destacarse la labor efectuada por Maldita.es, organización sin ánimo de lucro que se dedica a verificar datos en España y que forma parte del Grupo de expertos de alto nivel de la Comisión Europea contra la desinformación. A través de https://maldita.es/malditobulo/2020/05/11/coronavirus-bulospandemia-prevenir-virus/ puede verificarse la cantidad de desinformación vertida en torno al Covid desde diversas perspectivas.

16 Tales datos se han obtenido del estudio elaborado por Kleis Nielsen, R; Fletcher, R; Newman, N; Scott Brennen, J y N. Howard, P. (2020). «Navigating the 'infodemic': how people in six countries access and rate news and information about coronavirus». Reuters Institute, University of Oxford. Disponible en https://reutersinstitute.politics.ox.ac.uk/infodemic-how-people-six-countries-access-and-rate-newsand-information-about-coronavirus

(C) UNED. Revista de Derecho Politico

N. ${ }^{\circ} 109$, septiembre-diciembre 2020, págs. 229-260 
dificultades de coordinación y cooperación entre Estado y Comunidades Autónomas ${ }^{17}$. Esa ausencia de coordinación, ha reflejado además una falta de uniformidad en los criterios metodológicos para recabar los datos con repercusión internacional ${ }^{18}$. No obstante, ha de destacarse el esfuerzo de algunas CCAA por ser transparentes y aprovechar la dificultad de los tiempos para alzarse por encima de otras autonomías e incluso del propio Estado, en materia de transparencia y acceso a la información pública ${ }^{19}$.

En cualquier caso, la falta de seguridad informativa en el sentido anteriormente expuesto, manifiesta un riesgo evidente de descrédito que se cobra como víctima principal la transparencia del sistema ${ }^{20}$. Y es que cuando no se actúa con criterios de calidad, comprensibilidad y transparencia el riesgo de desconfianza se acrecienta, produciéndose una negación ciudadana a la «infodemia». Se produce entonces nuevamente la paradoja de la desinformación. Esto es, frente a toda esa oleada informativa, que abarca desde la difusión de gran cantidad de información hasta la manipulación y sesgo informativo, se produce un fenómeno preocupante y es que el ciudadano, colapsado con esa «infodemia», empieza a rechazar la información por razones de descrédito y desconfianza.

Otra cuestión polémica que se ha dado en el escenario actual y que contribuye a acrecentar la desconfianza, ha sido la suspensión de los plazos para la tramitación de las solicitudes de acceso a la información. Las peticiones de información amparadas en la LTAIBG se han visto directamente paralizadas al albor de la Disposición Adicional Tercera del Real Decreto 463/2020, de 14 de marzo, por el que se declara el estado de alarma. Dicha suspensión ha sido corroborada expresamente en el apartado B. 5) de la nota informativa publicada en el Portal de Transparencia por el Ministerio de Política Territorial y Función Pública, el pasado 17 de abril de $2020^{21}$. Se trata de

17 Puede consultarse al respecto la noticia «Los diferentes criterios con los que se recogen los datos...», cit.

18 En este sentido destaca la rectificación de la OCDE para bajar a España en el ranking sobre diagnóstico del COVID19 del puesto 8 al 17 en número de test realizados porque los datos aportados por el Gobierno español incorporaban test PCR y pruebas serológicas cuando los datos obtenidos por la OWID para el resto de países solo computaban los PCR. Sobre dicha problemática en el sentido expuesto pueden consultarse entre otros «La OCDE rectifica y baja a España del octavo puesto al decimoséptimo en número de test de coronavirus realizados». (28 de abril de 2020). El País. En éste último se pone de manifiesto el problema anterior con la falta de información autonómica. En cuanto a la problemática internacional generada al respecto puede verse «The Covid-19 pandemic has catapulted one mysterious data website to prominence, sowing confusion in international rankings». (19 de mayo de 2020). CNN.

19 Al respecto el interesante artículo de BERNARDO, A. (2020). «La transparencia sobre las pruebas diagnósticas del coronavirus avanza a varias velocidades», Civio. Disponible en https://civio.es/ medicamentalia/2020/05/13/coronavirus-covid-19-pcr-pruebas-datos-transparencia/

20 En tal sentido se ha pronunciado en artículo de opinión, DE LA NUEZ CASCADO, E. (21 de abril de 2020). «Transparencia, libertad de información y Covid-19». El Español.

21 En dicho apartado del informe se establece expresamente que «nos encontramos ante una suspensión temporal vinculada al estado de alarma. Las unidades de transparencia están trabajando de forma activa en la tramitación interna de las solicitudes para evitar que se produzca acumulación y para 
una cuestión sumamente controvertida que ha sido cuestionada por expertos y organizaciones en pro del derecho de acceso, solicitando al Gobierno la reanudación de los plazos para la tramitación de las solicitudes de acceso a la información ${ }^{22}$.

Dicha suspensión de plazos ha puesto de manifiesto la necesidad de seguir profundizando en la cultura de la transparencia. Y es que por un lado, no se entienden ni se explican los motivos que llevan a la suspensión de este derecho. Medida que habría exigido una justificación razonada en la medida en que como advierte BLANES CLIMENT «cuando se suspende el derecho de acceso a la información pública, se está suspendiendo también derechos fundamentales: a comunicar o recibir libremente información veraz por cualquier medio de difusión (art. 20.1.d), a participar en los asuntos públicos (art. 23.1) y a acceder a la información pública cuando lo ejercita un cargo electo (concejal, diputado o senador)» ${ }^{23}$. Así pues, atendiendo al espíritu democrático que descansa en el derecho de acceso a la información pública y en la conexión que ostenta para el disfrute de otros derechos, se hace sumamente difícil justificar una suspensión in abstracto de este tipo.

Por otro lado, la decepción en la doctrina respecto a la suspensión de los plazos para las solicitudes de acceso a la información ha traído causa de la frustración que supone dicha suspensión en aras a satisfacer la finalidad del acceso a la información. Así, se ha dicho que «el problema, claro está, es que esta información es relevante precisamente ahora y no más tarde, ya que se trata de obtener datos que puedan permitir a los ciudadanos monitorizar (...) la actuación del Gobierno, CCAA y entidades locales en esta crisis y exigir, en su caso, la correspondiente rendición de cuentas, ya sea política, administrativa o judicial» ${ }^{24}$. Por tanto, aunque se justifique que de la suspensión de los plazos no se deriva una suspensión del derecho en sentido material, de facto puede llegar a producirse una suspensión si con ello se impide satisfacer la finalidad del derecho.

No obstante, debe mencionarse que esta suspensión no rige en lo relativo a las obligaciones de publicidad activa en los contratos de emergencia suscritos para hacer frente a la crisis sanitaria. De modo que, aunque un contrato de emergencia (art. 120 de la Ley 9/2017, de contratos del sector público (LCSP)), justifique la reducción del procedimiento, no debe recortar en transparencia. Destaca también el art. 8.1.a) LTAIBG que somete a deber de publicidad la suscripción de todos los contratos celebrados por parte de los sujetos obligados. No obstante, la problemática en torno

estar en disposición de responder lo antes posible. Se responderán las solicitudes permitiendo así la rendición de Cuentas». Disponible en https://transparencia.gob.es/transparencia/dam/jcr:f3abf704-ff104dbd-b80a-be6bf36a22d5/NotaInformativaFuncionamientoPortalTransparencia.pdf

22 Sobre tal iniciativa véase Access Info. «España: la Coalición Pro Acceso pide al Gobierno que garantice el derecho de acceso a la información durante la crisis de la Covid-19». (27 de abril de 2020). Disponible en: https:/www.access-info.org/es/blog/2020/04/27/espana-acceso-informacion-covid19/

23 Cfr. BLANES CLIMENT, M.A. (2020). «Comentarios a la Nota del Portal de Transparencia...», cit.

24 Cfr. DE LA NUEZ CASCADO, E. (21 de abril de 2020) «Transparencia, libertad de información...», cit.

(C) UNED. Revista de Derecho Político

N. ${ }^{\circ} 109$, septiembre-diciembre 2020, págs. 229-260 
al retraso en publicar tales contratos se ha saldado cuando, tras la presión ejercida por la sociedad civil, la Junta Consultiva de Contratación Pública del Estado emitió una nota informativa que vino a ratificar en efecto la sumisión de la contratación de emergencia a reglas de transparencia ${ }^{25}$.

Lo cierto es que como ha señalado PIÑAR MAÑAS el derecho a saber, «está en la base misma de la transparencia y el acceso a la información, debe ser ahora más reivindicado que nunca. Información que alcanza también a todos los datos sobre la evolución de la pandemia y sobre la gestión económica que desde los poderes públicos se está llevando a cabo, incluida la referida a adquisiciones de material, coste, adjudicatarios y en general celebración de contratos» ${ }^{26}$. En este sentido, es importante que se facilite la información a la ciudadanía para poder conocer cómo nuestros represen-

25 En dicho informe se declara que «el artículo 120 LCSP excluye la obligación de tramitar el expediente de contratación, y por tanto la necesidad de publicar el anuncio previo y los trámites de dicho expediente. La LCSP no recoge, en cambio, especialidades para estos contratos en relación a la publicidad de los actos de adjudicación y formalización en el perfil de contratante del órgano de contratación respecto al régimen de publicidad previsto con carácter general por los artículos 151.1 y 154.1 de la LCSP. La publicación en estos casos deberá limitarse, no obstante, a lo que resulte pertinente teniendo en cuenta que no existe un procedimiento previo con los trámites habituales. En este sentido cobran importancia, por ejemplo, aspectos como los siguientes: la justificación del procedimiento utilizado para la adjudicación, la mención del objeto del contrato, el precio de adjudicación o la identidad del contratista». Disponible en: https://www.hacienda.gob.es/Documentacion/Publico/D.G.\%20PATRIMONIO/Junta\%20Consultiva/ Notas/NOTA\%20EMERGENCIA\%20COVID-19\%20F.pdf

26 Cfr. PIÑAR MAÑAS, J.L. (2020). "Contra los bulos, transparencia. O sobre cómo la transparencia y el derecho a saber son exigencias democráticas también (o aún más) en estado de alarma». Hay Derecho, Expansión. Respecto a los contratos de emergencia ha puntualizado Access info «Transparencia e integridad en la contratación pública. Garantizar la transparencia de la contratación de emergencia: Recomendaciones», p.2, que «si bien se necesita cierta flexibilidad para hacer llegar los suministros a los ciudadanos, esta no debe comprometer la transparencia. La transparencia y los datos abiertos son sumamente importantes para ayudar a evitar la corrupción en la contratación pública». Por su parte, Transparencia Internacional España también ha lanzado una serie de recomendaciones para evitar la corrupción en el marco de la contratación de emergencia. En tal sentido, Transparencia Internacional España (mayo de 2020). «Transparencia y publicidad activa: covid-19 y estado de alarma en España Recomendaciones para la transparencia y prevención de la corrupción en el sector público y privado». Disponible en https://transparencia.org.es/wp-content/uploads/2020/05/Transparencia-ypublicidad-activa-recomendaciones-COVID19.pdf. GAMERO CASADO, E. (2020). «Transparencia y contratación de emergencia ante el Covid-19», Observatorio de Contratación Pública, ha señalado en esta línea que que «todos los contratos que se estén formalizando deben hacerse públicos. Los ciudadanos tenemos derecho a saber, por ejemplo, quién es el intermediario que compró en China test defectuosos, cuánto han costado los test y cuánto ha cobrado el intermediario. Podemos —y debemos— hacernos ese tipo de preguntas en relación con todos los contratos de emergencia que vienen firmando todas las Administraciones: el Estado, las Comunidades Autónomas y las Entidades Locales. Es más, esta garantía de transparencia es tanto más necesaria cuanto que se suprime la fase de licitación y su correlativa publicidad. La completa opacidad del procedimiento de contratación de emergencia debe verse correspondida con absoluta transparencia en la gestión». Sobre este mismo autor y en el mismo sentido véase su interesante artículo de opinión GAMERO CASADO, E. (11 de abril de 2020). «La contratación de emergencia ante el coronavirus no puede ser un 'cheque en blanco'». Vozpópuli. 
tantes están llevando a cabo la gestión de la crisis sanitaria, y ello en base a la información aportada sobre un asunto de interés público como éste.

Como ha señalado GIMENO FELIÚ, »en el contexto social actual se exige más explicación y más rendición de cuentas de las decisiones de contratación adoptadas (y con quienes y sus importes) pues la ciudadanía, (...) tiene el derecho a conocer como contraprestación a un «esfuerzo solidario colectivo» sin precedentes. Y esto no es burocracia innecesaria. Esto es democracia, pues el virus COVID-19 no puede traspasar su ámbito natural sanitario para afectar a las fronteras de lo público para favorecer espacios de opacidad. La transparencia es un escudo que, por tanto, debe ser reforzado ${ }^{27}$. Esta idea es sumamente remarcable y extrapolable a la problemática sobre la falta de transparencia en la composición del grupo de expertos que asesora al Gobierno en el proceso de desescalada.

La decisión del Gobierno de mantener dicha composición a puerta cerrada hasta el momento, ha generado gran desconcierto y no sin razón. Por un lado, desde la perspectiva normativa no se entiende tal opacidad cuando el art. 3.f) de la Ley 33/2011, de 4 de octubre, General de Salud Pública establece como principio general de actuación la transparencia de las administraciones en materia de salud pública ${ }^{28}$. Pero más concretamente para el caso, el art. 11 de la citada ley establece el carácter público de la composición de comités evaluadores sobre ámbitos de salud pública ${ }^{29}$. A lo que el art. 15.2 de la LTAIBG añade que, «con carácter general, (...), se concederá el acceso a información que contenga datos meramente identificativos relacionados con la organización, funcionamiento o actividad pública del órgano» ${ }^{30}$.

Esa falta de voluntad política por hacer disponible la información, no parece ampararse en ninguna causa que justifique interés público alguno. Pues en definitiva «se trata de personas que, en su calidad de expertos, y con independencia de su rela-

27 Cfr. GIMENO FELIÚ, J.M. (2020). «La crisis sanitaria covid-19. Reflexiones sobre su incidencia en la contratación pública y las soluciones adoptadas». Jornada organizada por Regulation and Digital Innovation Research Group UV y Observatorio 155, p.6. Texto disponible en http://www.obcp.es/sites/ default/files/2020-04/LA-CRISIS\%20SANITARIA\%20COVID-19.\%20REFL\%20EXIONES\%20 SOBRE $\% 20$ SU $\% 20$ INCIDENCIA $\% 20$ EN $\% 20$ LA $\% 20$ CONTRATACIOi $\%$ CC $\% 80 N \% 20$ PUi\%CC\%80BLICA\%20Y\%20LAS\%20SOLUCIONES\%20ADOPTADASv2.pdf

Sobre este mismo autor y con mayor profundidad sobre la materia puede consultarse GIMENO FELIÚ, J.M. (2020). «La crisis sanitaria covid-19 y su incidencia en la contratación pública». El Cronista del Estado Social y Democrático de Derecho, ejemplar dedicado a Coronavirus y otros problemas, ${ }^{\circ}$. 86-87, págs. 42 a 53.

28 El art. 3.f) de la Ley 33/2011, de 4 de octubre, General de Salud Pública señala que «Las actuaciones de salud pública deberán ser transparentes. La información sobre las mismas deberá ser clara, sencilla y comprensible para el conjunto de los ciudadanos».

29 Así, el art. 11 de la Ley 33/2011, de 4 de octubre, General de Salud Pública dispone que «será pública la composición de los comités o grupos que evalúen acciones o realicen recomendaciones de salud pública, los procedimientos de selección, la declaración de intereses de los intervinientes, así como los dictámenes y documentos relevantes, salvo las limitaciones previstas por la normativa vigente».

30 Art. 15.2 de la LTAIBG.

(C) UNED. Revista de Derecho Politico

N. ${ }^{\circ} 109$, septiembre-diciembre 2020, págs. 229-260 
ción jurídica con la Administración (...), están desempeñando funciones públicas de asesoramiento especial al Ministerio de Sanidad y, por tanto, al Gobierno ${ }^{31}$.

Además, desde una perspectiva jurisprudencial habría que señalar igualmente que los precedentes existentes son proclives a la publicación de este tipo de información. Ha habido ya varios pronunciamientos a favor de la identificación del personal que integra comités de este tipo, entre los que recientemente destacan las sentencias de la Audiencia Nacional 61/2018, de 4 de mayo de 2018 y 51/2019, de 18 de diciembre de $2019^{32}$. En la primera de las sentencias citadas se mantiene taxativamente en el FJ3 que, «la circunstancia de que el contenido de una nota (...) no excluye la posibilidad de que los ciudadanos interesados conozcan la identidad de quienes hayan participado en su elaboración. Por el contrario, la transparencia consiste cabalmente en la visibilidad de lo que hay y de los que están detrás de las declaraciones formalizadas de conocimiento o de voluntad de las Administraciones y, singularmente, en la posibilidad de conocer la identidad de las personas que, integradas en su organización o incluso desde fuera de ella, han tomado parte o han influido en su elaboración» ${ }^{33}$.

Por su parte, la segunda sentencia de la Audiencia Nacional resulta interesante en tanto que la Administración en este caso sostenía que, «el deber de identificación se refiere tan solo al órgano en sí mismo considerado y no a la identidad de los miembros del mismo, es decir, de las personas» ${ }^{34}$. Sin embargo, la Audiencia Nacional ratifica la sentencia del juez de instancia reiterando que «no es indiferente para el derecho al acceso de información que quien pondera, informa, valora, enjuicia o recomienda o no recomienda oportunamente la generación de una alerta o la retirada de un producto sanitario que concierne a esos bienes y derechos constitucionalmente protegidos tenga o no tenga la cualificación correspondiente para hacerlo y que sea identificable o no lo sea, según su profesión, oficio y datos personales con tal carácter técnico y sanitario exigible al respecto. El derecho de acceso a la información es un derecho reconocido de forma amplia y solo puede ser limitado en los casos y en los términos previstos en la Ley (...)» ${ }^{35}$.

Con los precedentes normativos y jurisprudenciales expuestos en párrafos anteriores resulta difícil justificar la negativa en publicar la composición del órgano asesor sobre la desescalada. No puede entenderse proporcional a las circunstancias actuales,

31 Cfr. BLANES CLIMENT, M.A. (2020). «Tenemos derecho a saber quiénes son las personas expertas del Ministerio de Sanidad sobre el Covid-19 y a conocer sus informes». Blog de Transparencia y Gobierno Abierto — Transparency and Open Government.

32 Al respecto, véase «La justicia tumba los comités opacos y los informes apócrifos como los del Gobierno». (10 de mayo de 2020). El Confidencial.

33 Sentencia de la Audiencia Nacional, Juzgado Central de los Contencioso Administrativo n ${ }^{\circ}$ 12, 61/2018, de 4 de mayo de 2018, FJ 3.

34 Cfr. Sentencia de la Audiencia Nacional, Sala de lo Contencioso-Administrativo, 51/2019, de 18 de diciembre de 2019, FJ4.

35 Cfr. Sentencia de la Audiencia Nacional, Sala de lo Contencioso-Administrativo, 51/2019, de 18 de diciembre de 2019, FJ4. 
la postura renuente del Gobierno en un asunto que afecta al país en su conjunto y que exige una gestión cristalina de la crisis sanitaria.

El derecho de acceso a la información pública es per se, engranaje democrático de la sociedad. No en vano, su carácter democratizador despliega todo el sentido cuando como ahora, se constituye como requisito sine qua non para la formación de la opinión pública libre. En esta línea, el TEDH ha destacado recientemente a propósito del caso Szurovecz vs. Hungría, de 8 de octubre de 2019, que «la función de «guardián» de los medios de comunicación adquiere especial importancia (...), ya que su presencia es una garantía de que se puede pedir cuentas a las autoridades por su conducta» ${ }^{36}$. Pero además, resulta necesario destacar que el TEDH ha tenido ocasión de pronunciarse ya durante la pandemia sobre la importancia del derecho de acceso a la información pública en relación con datos que afectan a representantes políticos y que han de ser sometidos a escrutinio ${ }^{37}$, en el asunto Centro para la Democracia y el Estado de Derecho vs. Ucrania, de 26 de marzo de $2020^{38}$.

Tales conclusiones del TEDH resultan aplicables al contexto actual, y se mueven en torno a la idea expuesta por el escritor NOAH HARARI. «La mejor defensa que tienen los humanos contra los patógenos no es el aislamiento, sino la información» ${ }^{39}$. No puede haber mejor definición del papel que ocupa la información en la lucha contra esta pandemia global. Hace falta información y acceso a la misma en condiciones de calidad, para saber a qué nos enfrentamos como sociedad y cómo hacerlo. De este modo, garantizando el derecho de acceso a la información pública principalmente se logran dos objetivos: por un lado, contener el miedo y la incertidumbre, otorgando seguridad jurídica. Por otro lado, reforzar la realización del Estado democrático de Derecho, a través del lazo que estrecha la transparencia y el principio democrático. En este sentido, el papel vigilante del derecho de acceso a la información permite al ciudadano fiscalizar la acción pública, a la vez que exige al poder público la rendición de cuentas. Esta vertiente del derecho de acceso se constituye como una herramienta

36 Cfr. STEDH asunto Szurovecz vs. Hungría, de 8 de octubre de 2019, p. 61

37 Así, asunto Centro para la Democracia y el Estado de Derecho vs. Ucrania, de 26 de marzo de 2020. Sobre este caso han destacado Ó FATHAIGH, R y VOORHOOF, D. (27 de abril de 2020). «Refusal to give access to 'confidential' information about politicians violated NGO's Article 10 rights». Strasbourg Observers, que «This judgment, delivered during the Covid-19 pandemic, clearly illustrates how important it is, more than ever, that the Court applies strict scrutiny under Article 10 in cases on access to public documents, recognising the importance of transparency on matters of public interest». Disponible en https://strasbourgobservers.com/2020/04/27/refusal-to-give-access-to-confidentialinformation-about-politicians-violated-ngos-article-10-rights/

38 Este caso interesa especialmente al señalar el tribunal en el p. 99 que se ha vulnerado el art. 10 CEDH por denegar el acceso a información relativa a los currículums de los políticos afectados por cuanto «los individuos involucrados, los principales políticos, eran figuras públicas de particular importancia. El Tribunal acepta que el público tenía interés en su historial e integridad en el contexto inmediatamente posterior a las elecciones»,

39 Cfr. «Yuval Noah Harari: «La mejor defensa contra los patógenos es la información». (22 de marzo de 2020). El País.

(C) UNED. Revista de Derecho Politico

N. ${ }^{\circ} 109$, septiembre-diciembre 2020, págs. 229-260 
persuasiva de acercamiento ciudadano a la vida pública y a nuestros representantes, que puede contrapesar la preocupante tendencia por la desafección informativa.

Desconfiar de la información pública conlleva un descrédito insostenible para la legitimación democrática de nuestras instituciones. Por eso, hoy más que nunca la reconciliación y el acercamiento deben producirse a través de la palabra, y para ello es dable exigir información. En este sentido, no basta con atribuir la responsabilidad a los tiempos convulsos que ha tocado enfrentar, sino que resulta necesaria una actuación proactiva para mejorar en transparencia. Así, avanzar en calidad democrática exige deconstruir las señaladas narrativas insolidarias, la información intoxicada por finalidades distintas a la opinión pública y el temor al escrutinio. Solo así se logrará labrar el camino hacia la cultura definitiva de la transparencia.

Una vez destacada la importancia del derecho de acceso a la información pública en el contexto actual, se profundizará sobre el mismo a propósito del constitucionalismo multinivel. La crudeza del contexto actual ha mostrado la necesidad de seguir reforzando el derecho objeto de estudio, y para ello se tratarán de escenificar dos cuestiones esenciales para el constitucionalismo contemporáneo: cómo casan los problemas de integración propios del multinivel con un derecho de acceso a la información pública que exige insistir en su estudio desde una doble perspectiva interna e internacional.

\section{BREVE REFERENCIA AL CONSTITUCIONALISMO MULTINIVEL EN EL CONTEXTO ACTUAL.}

El proceso de globalización e integración europea han puesto de manifiesto que la tutela de los derechos ha superado la exclusividad constitucional inherente al ámbito nacional. En este sentido, la teoría del constitucionalismo multinivel surge en el proceso de integración europea para tratar de explicar y dar sentido a las relaciones entre los distintos planos constitucionales que garantizan los derechos ${ }^{40}$. Dicha construcción surge del debate sobre la necesidad de una Constitución para Europa, y resulta ser un concepto acuñado por PERNICE para entender la UE y superar los

40 Vid. BALAGUER CALlEjÓN, F. (2008). «Constitucionalismo multinivel y derechos fundamentales fundamentales en la Unión Europea», en Estudios en Homenaje al profesor Gregorio PecesBarba, Dykinson, vol. 2, p. 133. Sobre el estudio de los derechos en el marco del constitucionalismo multinivel señala oportunamente Cfr. CASCAJO CASTRO, J. L. (2008). «Interpretación constitucional y constitucionalismo multinivel», en FERRER MAC-GREGOR, E., y ZALDÍVAR LELO DE LARREA, A, (Coords.), La ciencia del Derecho Procesal Constitucional Estudios en homenaje a Héctor FixZamudio en sus cincuenta años como investigador del Derecho, México, UNAM, Vol. IV, p. 201. Disponible en https://archivos.juridicas.unam.mx/www/bjv/libros/6/2560/12.pdf; que «uno de los presupuestos conceptuales que favorecen la óptica multinivel de los derechos fundamentales puede ser, su configuración como el «antisoberano». De modo que alejándose de las visiones soberanistas clásicas, que acentúan el nexo estatal-territorial de las distintas posiciones jurídicas subjetivas del ciudadano, se pretende buscar otro tipo de legitimidad». 
déficits de legitimidad democrática ${ }^{41}$. Se parte aquí de la idea de que Europa ya cuenta con una Constitución material gracias a las aportaciones realizadas por los tratados comunitarios y las Constituciones nacionales.

No obstante, esa idea de Constitución material europea en el contexto multinivel sigue sin resolver los problemas de legitimidad democrática de los que adolece la UE. Así, aunque se haya sostenido que la configuración multinivel propia del proceso de integración sirve como guía en la cohesión entre ordenamientos ${ }^{42}$, sigue faltando algo y es que «Europa (...) quizás necesita hoy un paso adelante, con el que se reafirmaría también la especial << aptitud constitucional >> de la Unión Europea» ${ }^{43}$. Mientras ese proceso democratizador no culmine, seguirá tratándose de un modelo incompleto desde la perspectiva constitucional y política de integración ${ }^{44}$.

Es cierto que la construcción multinivel ha permitido sostener con amplio margen de unidad y conexión, subsistemas plurales y diversos. De ahí que sus propias características le hagan protagonista de una importante influencia en el estudio de los derechos fundamentales. De este modo, cada uno de estos niveles, - el internacional, supranacional europeo y nacional-, entretejen el complejo multinivel con las singularidades que le son propias. En este contexto plural se habla de «una triada de niveles y técnicas de garantía de los derechos generadora de un diálogo entre tribunales que se puede caracterizar, en principio, como un fenómeno positivo para el desarrollo de los derechos fundamentales» ${ }^{45}$. Ese diálogo entre tribunales, alude al «trabajo en red ${ }^{46}$ efectuado por parte de los tribunales nacionales, TEDH y TJUE, para conformar un sistema armónico en la interpretación de los derechos. No obstante, este diálogo ha sido identificado también como un apelativo para endulzar ${ }^{47}$ en cierto modo las dificultades propias del sistema multinivel.

41 Vid. PERNICE, I. (2015). «Multilevel Constitutionalism and the Crisis of Democracy in Europe». European Constitutional Law Review, n 11 , p. 541.

42 Vid. SCARLATTI, P. (2011). Democracia y teoría de la legitimación en la experiencia de la integración europea. Contribución a una crítica del constitucionalismo multinivel. Servicio editorial de la Universidad del País Vasco, p. 100.

43 Cfr. HÄBERLE, P. (2004). «Europa como comunidad constitucional en desarrollo». Revista de Derecho Constitucional Europeo, $\mathrm{n}^{\circ} 1$. En esta misma línea se pronuncia sobre la necesidad de una Constitución para Europa, BALAGUER CALLEJÓN, F. (2004). «Niveles y técnicas internacionales e internas de realización de los derechos en Europa. Una perspectiva constitucional». Revista de Derecho Constitucional Europeo, $\mathrm{n}^{\circ} 1$.

44 Sobre la falta de unidad política en la UE, puede verse en el mismo sentido Vid. MONEREO PÉREZ, J.L. (2016). «El constitucionalismo social europeo ante los nuevos poderes soberanos», en GARCÍA HERRERA, M.A, ASENSI SABATER, J, BALAGUER CALLEJÓN, F, et al. Constitucionalismo crítico: Liber amicorum Carlos de Cabo Martín, Tirant lo Blanch, vol. 1, p. 907.

45 Cfr. BALAGUER CALLEJÓN, F. (2004). «Niveles y técnicas internacionales...», cit.

46 Cfr. GARCÍA ROCA, J. (2018). «La transformación del Convenio europeo de derechos humanos». Revista General de Derecho Constitucional, $\mathrm{n}^{\circ}$ 18, p. 9.

47 Vid. OlLERO TASSARA, A. (2018). «Diálogo de Tribunales en el marco europeo», en DE LUCAS MARTÍN, F. J; VIDAL GIL, E. J Y FERNÁNDEZ RUIZ-GÁLVEZ, E (Coords.) Pensar el tiempo presente. Homenaje al profesor Jesús Ballesteros Llompart, Tirant lo Blanch, vol. 1, 2018, págs. 27 y 28.

(C) UNED. Revista de Derecho Político

N. ${ }^{\circ} 109$, septiembre-diciembre 2020, págs. 229-260 
Entre las ventajas comúnmente atribuidas al constitucionalismo multinivel se ha dicho que refleja la situación real de los derechos atendiendo a cada uno de los ordenamientos ${ }^{48}$. Es más, podría añadirse que gracias a la articulación del sistema multinivel, algunos derechos como es el caso del acceso a la información pública, han ampliado y enriquecido su alcance y contenido. Ahora bien, volviendo a la mencionada aptitud constitucional europea encontramos un importante freno que a su vez dificulta el proceso de integración. En Europa existe un sistema dual de protección de los derechos entre dos organizaciones muy distintas - Consejo de Europa y Unión Europea-, que no goza de plena integración. Esto puede comprobarse en la reticencia europea en adherirse como parte al $\mathrm{CEDH}^{49}$, ya que muestra el temor del TJUE por perder su monopolio en la interpretación del Derecho de la Unión ${ }^{50}$. No en vano, cabe recordar que la ratificación del CEDH por parte de la UE no se prevé como una potestad facultativa, sino con carácter imperativo, vía art. 6.2 TUE. Por tanto, sigue siendo ésta una tarea pendiente para el constitucionalismo europeo, que no sin dificultades, auspicia una mayor armonización en la protección de los derechos y una evolución en integración europea ${ }^{51}$.

El recurso a la teoría del constitucionalismo multinivel también presenta sus dificultades, sobre todo cuando se trata de articular los distintos sistemas de control jurisdiccional TEDH-TJUE ${ }^{52}$. En este sentido y a modo de breve paréntesis, debe tenerse en cuenta que no existe unanimidad doctrinal con esta forma teórico-jerárquica de entender el constitucionalismo. HÄBERLE se opone al concepto de constitucionalismo multinivel entendiendo que «contiene en sí mismo una negación, dado

48 GÓMEZ SÁNCHEZ, Y. (2018). Constitucionalismo multinivel. Derechos fundamentales. Madrid, Sanz y Torres, $4^{a}$ edición, p. 49.

49 Se pronuncia críticamente en este mismo sentido, Vid. GARCÍA ROCA, J. (2018). «La transformación del Convenio europeo...», cit., págs. 6 y 8.

En efecto el TJUE vetó la posible ratificación del CEDH, cuando consideró en el Dictamen 2/13 del Tribunal de Justicia, de 18 de diciembre de 2014, que el Proyecto de acuerdo de adhesión no era compatible ni respetaba la autonomía del Derecho de la Unión ni las características y singularidades propias de la UE.

${ }^{50}$ Entre otros se muestran críticos por la negativa del TJUE a la adhesión del CEDH, MARTÍN Y PÉREZ NANCLARES, J. (2015). «El TJUE pierde el rumbo en el Dictamen 2/13: ¿merece todavía la pena la adhesión de la UE al CEDH?». Revista de Derecho Comunitario Europeo, no 52, p. 830 y ss.

51 En el mismo sentido se pronuncia, Vid. GARCÍA ROCA, J. (2012). «El diálogo entre el Tribunal Europeo de Derechos Humanos y los Tribunales constitucionales en la construcción de un orden público europeo». Teoría y realidad constitucional, $\mathrm{n}^{\circ} 30$, págs. 184 y 185 . Sobre esta cuestión han señalado VAN DE HEYNING, C y LAWSON, R. (2011). "The EU as a party to the European Convention of Human Rights: EU law and the European Court of Justice case law as inspiration and challenge to the European Court of Human Rights jurisprudence», en POPELIER, P., VAN DE HEYNING, C., VAN NUFFEL, P (Eds.) Human rights protection in the European legal order: The interaction between the European and the national courts, Cambridge, Intersintia, p.60, que «la jurisprudencia de Luxemburgo podría tener un rol más visible como inspiración en relación a la interpretación de los derechos y libertades del Convenio».

52 En este sentido se pronuncia GÓMEZ SÁNCHEZ, Y. (2018). Constitucionalismo multinivel..., cit., p. 116. 
que su estructura jerárquica es cuestionable: los momentos constitucionales en el Derecho Internacional no están ni encima ni debajo del Derecho constitucional nacional o regional, se trata más bien de distintas relaciones de conexión (por ejemplo de complementariedad o cooperación) (...)» ${ }^{53}$. Frente a este término, HÄBERLE acuña el concepto de «constituciones parciales» para explicar que «el Derecho Constitucional Europeo completa, se superpone y se acumula a las constituciones nacionales (...)». De manera que según el autor, «hoy, el Estado Constitucional Cooperativo está condicionado por las constituciones parciales del Derecho Internacional o del Derecho Constitucional Europeo» ${ }^{54}$. La argumentación del autor pasa por «aceptar que las normas fundamentales europeas son también «nuestra» Constitución (...), porque son también parte de nuestra realidad constitucional». Así como a la inversa supone aceptar que «las normas constitucionales estatales tienen una proyección europea porque interaccionan con el nivel europeo generando nuevos desarrollos» ${ }^{55}$.

En cualquier caso, sea en base al concepto de constitucionalismo multinivel o de constituciones parciales, se coincide en esencia en un presupuesto básico y es la conexión en red y el diálogo entre tribunales ${ }^{56}$. Por otra parte, cuando se recurre al constitucionalismo multinivel como argumento legitimador de la UE, debe tenerse en cuenta que dicha teoría refleja una gran asimetría democrática entre el plano europeo y el interno, dificultando la consecución de una verdadera democracia en este contexto plural ${ }^{57}$. Se ha dicho en este sentido que la influencia recíproca entre el plano europeo y el nacional desemboca en una cierta deslegitimación del plano interno nacional ${ }^{58}$.

Resta decir que la idea de constitucionalismo multinivel como mecanismo para avanzar en la integración europea, no siempre es igual de operativa. En concreto, cuando nos referimos a la protección de derechos que gozan de perfiles distintos en cada plano, y que pueden plantear problemas de convergencia ${ }^{59}$.

53 Cfr. HÄBERLE, P. (2018). «El constitucionalismo como proyecto científico». Revista de Derecho Constitucional Europeo, $\mathrm{n}^{\circ} 29$.

54 Cfr. HÄBERLE, P. (2018). «El constitucionalismo como proyecto...», cit.

55 Cfr. BALAGUER CALLEJÓN, F. (2010). «La contribución de Peter Häberle a la construcción del Derecho constitucional europeo». Revista de Derecho Constitucional Europeo, $\mathrm{n}^{\circ} 13$.

56 Expresión utilizada en la doctrina constitucional, por todos, véanse entre otros, GARCÍA ROCA, J. (2012). «El diálogo entre el Tribunal Europeo de Derechos...», cit.; OLLERO TASSARA, A. (2018). «Diálogo de tribunales en el marco...», cit., p. 911 y ss.

57 Vid. BALAGUER CALLEJÓN, F. (2008). «Constitucionalismo multinivel y derechos fundamentales...», cit., págs. 146 y 147

58 En tal sentido, Vid. BILANCIA, P. (2006). «Las nuevas fronteras de la protección multinivel de los derechos». Revista de Derecho Constitucional Europeo, nº 6; Vid. BALAGUER CALLEJÓN, F. (2008). «Constitucionalismo multinivel y derechos fundamentales...», cit., págs. 146 y 147; Vid. CASCAJO CASTRO, J. L. (2008). «Interpretación constitucional...», cit., p. 201.

59 Vid. BILANCIA, P. (2006). «Las nuevas fronteras...», cit. 


\section{EL DERECHO DE ACCESO A LA INFORMACIÓN PÚBLICA EN EL MARCO DEL CONSTITUCIONALISMO MULTINIVEL.}

\section{1.a. El derecho de acceso a la información pública en el Consejo de Europa}

El reconocimiento de un derecho de acceso a la información pública en el marco del Consejo de Europa ha ido progresivamente en aumento. Esta tendencia no solo ha tenido reflejo en la actividad e iniciativas realizadas por parte de la Asamblea Parlamentaria y el Comité de Ministros del Consejo del Consejo de Europa, sino sobre todo en la jurisprudencia del TEDH.

Esta labor pretoriana del TEDH ha tenido como hilo conductor el reconocimiento del derecho de acceso a la información pública como exigencia democrática de la sociedad actual. En esta tarea, el CEDH juega un papel esencial por cuanto se afirma que es un «instrumento vivo (...) sometido a permanentes transformaciones que debe interpretarse de acuerdo al nowadays present condition: a la luz de las condiciones de vida actuales» ${ }^{60}$. Por eso puede decirse que, los derechos consagrados en el Convenio han ido desarrollándose y evolucionando, dando lugar a derechos nuevos o a nuevas interpretaciones y/o contenidos de viejos derechos ${ }^{61}$. Es por ello que, el TEDH haciendo uso de su capacidad interpretativa ha estimado que el derecho de acceso a la información pública forma parte del contenido inherente al art. $10 \mathrm{CEDH}$, -en el entendido de que se trata de un presupuesto democrático para la consecución de sociedades libres y participativas- ${ }^{62}$.

En este escenario cabe recordar la función cuasi-constitucional atribuida al TEDH en el ámbito regional europeo para la protección de derechos ${ }^{63}$ y su misión de garante dinamizador del CEDH. En el caso concreto del derecho de acceso a la información, el TEDH ha marcado un antes y un después con su jurisprudencia y ha sido la voz para generar necesarios debates en el ámbito nacional.

En esta importante tarea interpretativa, el TEDH ha redefinido y extendido el alcance del derecho a comunicar y recibir información del art. $10 \mathrm{CEDH}$, ya que aunque éste no alude al acceso a la información expresamente, el tribunal lo ha considerado como manifestación de aquel. La lógica utilizada por el TEDH parte de la consagración del derecho en el sistema universal de los derechos a través del art. 19 DUDH, y 19.2 del PIDCP. No obstante, la interpretación del TEDH en la materia

${ }^{60}$ Cfr. GARCÍA ROCA, J. (2018). «La transformación del Convenio europeo...», cit., p. 22.

61 Vid. GARCÍA ROCA, J. (2018). «La transformación del Convenio europeo...», cit., p. 59.

62 Entre la jurisprudencia más reciente del TEDH que se ha ido mostrado progresivamente favorable a dicha interpretación destacan los asuntos Társaság a Szabadságjogokért vs. Hungría, de 14 de abril de 2009; Kenedi vs. Hungría, de 26 de mayo de 2009; Youth Initiative for Humans Rights vs. Serbia, de 25 de junio de 2013; Guseva vs. Bulgaria, de 17 de febrero de 2015; Magyar Helsinki Bizottság vs. Hungría, de 8 de noviembre de 2016; Satakunnan Markkinapörss OY y Satamedia OY vs. Finlandia, de 27 de junio de 2017.

63 Sobre la función de órgano cuasi-constitucional del TEDH, Vid. RIPOL CARULLA, S. (2007). El sistema europeo de protección de los derechos humanos y el Derecho español. Barcelona, Atelier, p. 33 y ss. 
destaca sobre todo por la aportación realizada en el caso Magyar dictado por la Gran Sala en $2016^{64}$. Ya que con este caso se confirma el alcance instrumental del derecho de acceso a la información respecto del derecho a recibir información garantizado en el art. $10 \mathrm{CEDH}$, siempre que concurran los cuatro criterios de iusfundamentalidad que marca en el caso el tribunal—finalidad de la solicitud de información, naturaleza de la información, papel que desempeña el solicitante y disponibilidad de la información-. Más recientemente debe valorarse de forma muy positiva la labor jurisprudencial del TEDH en materia de acceso a la información en 2019 y 2020 ya que en estos dos últimos años se han dictado importantes asuntos, que no solo han aplicado los criterios nacidos en el asunto Magyar, sino que han trasladado al espacio público la gran repercusión democrática de este derecho ${ }^{65}$.

\section{1.b. El derecho de acceso a la información pública en la Unión Europea}

En la labor interpretativa atribuible al TJUE en el marco europeo, la CDFUE ejerce una importante función de apoyo. Se trata de un valioso instrumento que al ostentar valor jurídico vinculante, hace exigibles y ejercitables los derechos en ella reconocidos. Esto quiere decir que los Estados tendrán que prestar especial atención a la interpretación de los derechos fundamentales reconocidos en la Carta, sin olvidar que según el art. 51.1 CDFUE, su ámbito de aplicación queda limitado a los casos en los que los Estados miembros estén aplicando el Derecho de la Unión. Es decir, que la incidencia del derecho de la Carta sobre los poderes públicos nacionales depende de la actuación de éstos como aplicadores o ejecutores del Derecho europeo.

No obstante, en el caso concreto del derecho de acceso a la información pública de la UE cabría resaltar como positivo su reconocimiento expreso en el art. 42 CDFUE. Ya que tal reconocimiento sirve para identificar el derecho como pilar necesario de toda sociedad democrática, así como para constituir una guía de acción a favor de los Estados. No en vano, este derecho se erige como elemento esencial de los principios de apertura y transparencia en el actuar y funcionamiento democrático europeo $^{66}$, así como «mecanismo indispensable para contrarrestar el repetidamente señalado déficit democrático del que adolecían —y adolecen- las instituciones europeas» ${ }^{67}$.

64 STEDH Gran Sala, asunto Magyar Helsinki Bizottság vs. Hungría, de 8 de noviembre de 2016.

65 Entre la jurisprudencia más reciente del TEDH en materia de acceso a la información pública destacan los casos Affaire Cangi vs. Turquía, de 29 de enero de 2019; asunto Kablis vs. Rusia, de 30 de abril de 2019; Szurovecz vs. Hungría, de 8 de octubre de 2019; Studio Monitori y otros vs. Georgia, de 30 de enero de 2020; Centro para la Democracia y el Estado de Derecho vs. Ucrania, de 26 de marzo de 2020.

66 Vid. GONZÁLEZ ALONSO, L.N. (2008). «Artículo 42. Derecho de acceso a los Documentos», en MANGAS MARTÍN, A. (Dir.) y GONZÁLEZ ALONSO, L.N (Coord.) Carta de los Derechos Fundamentales de la Unión Europea. Comentario artículo por artículo. Madrid, Fundación BBVAA, 2008, págs. 680 y 681.

${ }^{67}$ Cfr. RAMS RAMOS, L. (2013). «La transformación del derecho de acceso en España: de derecho de configuración legal a derecho fundamental». Revista Española de Derecho Administrativo, $\mathrm{n}^{\circ}$ 160, p. 
Es decir, favorece el carácter democrático europeo en tanto que «más participación ciudadana en asuntos públicos significa mejor democracia» ${ }^{68}$. En este contexto, el derecho de acceso contenido en el art. 42 CDFUE así como en el art. 15.3 TFUE, ha sido desarrollado a través del Reglamento (CE) no 1049/2001 del Parlamento Europeo y del Consejo sobre el acceso del público a los documentos de las instituciones de la Unión Europea.

En lo relativo a la protección multinivel del derecho de acceso a la información pública, llama la atención su distinta configuración a expensas del plano internacional o supranacional europeo. Hemos visto como en el seno del Consejo de Europa el derecho en cuestión se reconoce como parte del contenido del art. $10 \mathrm{CEDH}$, vía pretoriana del TEDH. En cambio, en el plano europeo el derecho de acceso a la información sí goza de reconocimiento expreso, según dispone el art. 42 CDFUE. Ahora bien, el problema es que dicho reconocimiento no se vehiculiza a través de la libertad de expresión e información, sino que se consagra de forma autónoma en el precepto citado bajo el estatuto relativo a la ciudadanía ${ }^{69}$.

Las dos opciones planteadas muestran una diversidad de caminos, ambos loables, que llevan a consecuencias distintas a la hora de consagrar el derecho. Tales alternativas permiten discutir con razón acerca del encaje o cohesión multinivel entre la configuración europea del derecho de acceso y la desarrollada por el TEDH. Esta disparidad entre planos ha llamado la atención de parte de la doctrina y ha sido objeto de crítica. Se ha dicho que, la desvinculación entre acceso a los documentos (art. 42 CDFUE) y la libertad de expresión e información (art. 11 CDFUE), resta poder al derecho de acceso a la información, obviándose su verdadero sentido y significado ${ }^{70}$.

Otra interesante cuestión que suscita la protección multinivel del derecho de acceso la encontramos en la CDFUE. Así, cuando en las Explicaciones de la Carta relativas al art. 42 CDFUE se alude al art. 52.2 CDFUE se señala que «el derecho de acceso a los documentos se ejercerá en las condiciones y dentro de los límites establecidos por el art. 15.3 TFUE». Este último precepto reconoce en su párrafo $1^{\circ} \mathrm{el}$

\section{6.}

${ }_{68}$ Cfr. MONTILLA MARTOS, J. A. (2016). «Transparencia y acceso a la información en España», en SARLET, I. W; MONTILLA MARTOS, J.A; LINDEN RUARO, R (Coords.) Acesso à informaçao como direito fundamental e dever estatal. Porto Alegre, Livraria do Advogado Editora, p. 69.

69 Entre la jurisprudencia destacable del TJUE sobre el derecho de acceso a la información pública de la UE, destacan los asuntos C-58/94, asunto Holanda/Consejo, de 30 de abril de 1996; T-309/97, asunto Bavarian Lager/Comisión, de 14 de octubre de 1999; C-174/98 P y C-189/98 P, asuntos acumulados Países Bajos y Van der Wall/Comisión, de 11 de enero de 2000; Consejo/Hautala, asunto C-353/99, de 6 de diciembre de 2001; C-39/05 P y C-52/05 P, asuntos acumulados Suecia y Turco/Consejo, de 21 de septiembre de 2010; Comisión/Bavarian Lager, asunto C-28/08 P, de 29 de junio de 2010; T-233/09, asunto Access Info Europe/Consejo, de 22 de marzo de 2011 y T-540/15, asunto De Capitani/Parlamento Europeo, de 22 de marzo de 2018.

70 Vid. BLANES CLIMENT, M. A. (2014). La transparencia informativa de las administraciones públicas. El derecho de las personas a saber y la obligación de difundir obligación pública de forma activa. Navarra, Thomson Reuters, Aranzadi, p. 185. 
derecho de acceso de los ciudadanos a los documentos de las instituciones europeas, supeditando su ejercicio a los principios y límites, de interés público o privado, que desarrollen reglamentariamente el Parlamento Europeo y la Comisión. Surge aquí la cuestión de si el derecho se configura en la Carta como en el art. 105 de la Constitución española, esto es, bajo una reserva de desarrollo legislativo.

A tenor de lo anterior, subyace la idea de que aun atendiendo a la sacralización que el derecho de acceso a la información pública ha adquirido en el contexto internacional, parece que su ejercicio en el marco europeo se supedita o limita, a lo establecido reglamentariamente. Cabría aquí plantearse si late de fondo una limitación de la eficacia directa de la CDFUE, -y por tanto una limitación material de la acción del ciudadano europeo para hacer valer su derecho-, por cuanto el contenido del mismo se constriñe a su desarrollo legal.

\subsection{Problemas de integración multinivel a propósito del derecho de acceso a la información pública.}

En el marco de las relaciones entre tribunales cabe plantearse qué consecuencias podría tener para el derecho de acceso a la información la adhesión de la UE al CEDH. Una posibilidad sería entender que el hecho de que el derecho de acceso a la información pública ostente una interpretación distinta en el seno del Consejo de Europa y de la UE supone una verdadera contradicción. Contradicción que en caso de ratificación de la UE al CEDH, debería resolverse con un acercamiento de posturas entre ambos tribunales internacionales. En ese caso, ¿debería el TJUE sumarse sin condiciones a la interpretación del derecho de acceso a la información pública efectuada por el TEDH? ¿No podría esto afectar al principio de primacía y autonomía de la UE? Lo cierto es que la adhesión supondría una cierta sumisión material de la UE al $\mathrm{CEDH}^{71}$. Relación que se ha identificado como «una vía de intensificar el diálogo en materia de derechos fundamentales (...), entre el Tribunal de Justicia y el $\mathrm{TEDH} »^{72}$.

Otra posibilidad para el derecho de acceso derivada de la adhesión de la UE al $\mathrm{CEDH}$, sería entender que estamos frente a una mera discrepancia entre dichos tribunales, salvable en la medida en que no existe jerarquía entre ellos ${ }^{73}$. Esta opción sería viable sosteniendo que en base a los arts. 52.3 y 53 CDFUE no existe incompatibilidad derivada de esa divergencia interpretativa. Desde esta segunda opción, cabría llegar a la conclusión de que el sentido del art. 42 CDFUE debería ser el mismo que

71 Vid. HERMIDA, C. (2010). «Una salida a los conflictos entre el Tribunal de Estrasburgo y el Tribunal de Luxemburgo». Persona y Derecho, no 63, p. 130.

72 Cfr. FERNÁNDEZ ROZAS, J.C. (2014). «La compleja adhesión de la Unión Europea al Convenio Europeo de Derechos Humanos y las secuelas del Dictamen 2/2013 del Tribunal de Justicia». Revista La Ley Unión Europea, no 23, p. 51.

73 Vid. HERMIDA, C. (2010). «Una salida a los conflictos...», cit., p. 127.

(C) UNED. Revista de Derecho Politico

N. ${ }^{\circ} 109$, septiembre-diciembre 2020, págs. 229-260 
el otorgado en el art. $10 \mathrm{CEDH}$. Pues, aunque formalmente la CDFUE reconozca el derecho de acceso de forma independiente al derecho a la libertad de información del art. 11 CDFUE, el contexto citado permite establecer un puente entre ambos preceptos y conectar su contenido. Esta alternativa respetaría la consagración de los derechos efectuada en la CDFUE, en una interpretación pro libertate y en línea con la postura del TEDH.

El art. 52.3 CDFUE exige que el sentido y alcance de los derechos contenidos en la Carta que también estén reconocidos en el CEDH, se interpreten en base al canon de este último. Por su parte, el art. 53 CDFUE impide que los derechos reconocidos en la CDFUE se interpreten en contra de lo dispuesto en el CEDH. Así, teniendo en cuenta estos dos artículos cabría concluir que el sentido del art. 42 CDFUE debe ser el mismo que el otorgado en el art. $10 \mathrm{CEDH}^{74}$.

De lo dispuesto en el art. 52.3 CDFUE resulta que además que «esta disposición no obstará a que el Derecho de la Unión conceda una protección más extensa». La lógica de esta afirmación parte de la consideración de que el CEDH aporta un estándar de mínimos para la garantía de los derechos, por encima del cual tanto la UE como los Estados en base al margen de apreciación nacional, podrán crear protecciones más robustas. Sin embargo, en el caso particular del derecho de acceso a la información pública resulta paradójico que haya sido el TEDH el que haya construido una interpretación «formalmente de mínimos», pero materialmente más amplia para el derecho de acceso que la que encontramos en el resto de ordenamientos.

En casos como éste puede apreciarse el papel garantista del TEDH, que por razones obvias, otorga especial relevancia a la ratificación europea del CEDH. Valga en este sentido mencionar que seguir posponiendo dicha ratificación puede intensificar la bifurcación interpretativa en la jurisprudencia de ambos tribunales. Así, por más que en el marco del constitucionalismo multinivel se busque la armonización e integración entre planos constitucionales diversos, el problema por tanto apunta aquí a una posible relación disfuncional a futuro entre ambos tribunales. Y ello en tanto dicha relación no logre acoplarse debidamente en el proceso de integración, frenando así discrepancias más graves en la jurisprudencia de ambos tribunales.

Conviene ahora hacer una breve alusión al caso particular español. Pues en el ordenamiento español partimos de un reconocimiento del derecho de acceso a la información, vía art. $105 \mathrm{CE}$, mucho más limitado que en el ámbito global de las Naciones Unidas y regional europeo. Así, tomando como premisa el carácter evolutivo de la jurisprudencia internacional relativa al derecho en cuestión, resulta llamativo el retraso nacional en la configuración de su alcance y contenido. Esto se ha manifestado claramente con la actual crisis sanitaria manejada en el marco de la LTAIBG. En lo que respecta a esta última, puede concluirse que aun tratándose de una norma que

74 En este mismo sentido se pronuncia ROLLNERT LIERN, G. (2014). «El derecho de acceso a la información pública como derecho fundamental: una valoración del debate doctrinal a propósito de la ley de transparencia». Teoría y Realidad Constitucional, n 34, p. 362. 
pretendía saldar las carencias españolas en transparencia, la situación actual ha manifestado la falta de voluntad en su adecuado cumplimiento, y por ende, ciertas limitaciones en garantizar debidamente el derecho de acceso a la información.

Todo lo anterior aconseja un cambio de paradigma en España sobre el acceso a la información pública. La pandemia y las dificultades sociales, políticas y jurídicas que ha dejado a su paso deben ser el pretexto para la definitiva consolidación del derecho de acceso a la información pública en nuestro país. Así pues, atendiendo a las carencias manifestadas en la actualidad sobre la materia, y partiendo del progresivo reconocimiento internacional del derecho, habría que ajustar la regulación legal en España al estándar internacional, y con ello, vincularlo al art. 20.1.d) CE.

Sin perjuicio de la postura tradicional española seguida hasta el momento, siempre quedará abierta la posibilidad de retomar el debate sobre su reajuste constitucional. Así, teniendo en cuenta el canon de interpretación de los derechos que consagra nuestro art. 10.2 CE, y el hecho de que tanto el CEDH como la CDFUE son instrumentos jurídicos vinculantes (art. $96 \mathrm{CE}$ ), podemos preguntarnos cuál sería la interpretación más susceptible acogida en España para una definitiva reconfiguración en pos de la naturaleza fundamental del derecho. Subyace aquí la pregunta de si nuestro ordenamiento jurídico atendería a la interpretación efectuada por el TEDH, según la cual el derecho de acceso a la información es parte del derecho a recibir información del art. $10 \mathrm{CEDH}$, o si trataría más bien de crear un derecho ex novo desligado de la libertad de recibir información (art. 11 CDFUE), partiendo del carácter autónomo y expreso del que goza en el art. 42 CDFUE.

La segunda opción quedaría descartada en la medida en que la supremacía constitucional impide incluir aun por vía del art. 10.2 CE, derechos que no estén previamente consagrados en nuestra Constitución ${ }^{75}$. Bien es cierto que ciñéndonos a la segunda posibilidad planteada, resulta inviable elevar a categoría de fundamental el art. $105 \mathrm{CE}$, en tanto queda fuera del marco orgánico y especialmente protegido de la Sección I del Capítulo II del Título I de la CE. Sin embargo, este argumento no debe vetar ni obstaculizar otras alternativas que permitan ajustar el texto constitucional al marco multinivel y a las exigencias sociales actuales. Dentro de estas posibilidades se encontraría la de interpretar el art. 105 CE como instrumento y presupuesto necesario para la efectividad del art. 20.1.d) CE. Esta vía es en mi opinión es respetuosa con la supremacía constitucional y en particular con el art. 10.2 CE. Pues, ya no estaríamos creando un derecho nuevo, sino actualizando la interpretación de uno ya existente, art. 20.1.d) CE, a las exigencias del constitucionalismo actual.

75 Así lo ha declarado el TC en su jurisprudencia. Pueden consultarse entre otras, Vid. SSTC 64/1991, de 22 de marzo (FJ 4), 372/1993, de 13 de diciembre, $\left(F^{\circ} 7\right)$ y 41/2002, de 25 de febrero (FJ 2).

Sobre el alcance y contenido del art. 10.2 CE véase, CUENCA GÓMEZ, P. (2012). «La incidencia del Derecho Internacional de los derechos humanos en el Derecho Interno: la interpretación del art. 10.2 de la Constitución Española». Revista de Estudios Jurídicos, nº12, (versión electrónica), p. 8 y ss. 


\section{CONCLUSIONES.}

El presente artículo ha tratado de profundizar sobre el derecho de acceso a la información pública desde diversas perspectivas. Por un lado, se ha analizado la relevancia constitucional del acceso a la información pública, teniendo en cuenta el marco de la crisis sanitaria del COVID-19 en el que se ha visto envuelto y afectado. Ha podido comprobarse cómo el hecho de que España cuente con una norma de referencia en materia de transparencia y acceso a la información pública, la LTAIBG, no es del todo suficiente para garantizar de manera efectiva este derecho. Así, se han puesto de manifiesto los déficits y principales problemas generados en torno a la gestión de la crisis sanitaria en España, en lo que respecta a la efectividad del derecho de acceso a la información pública. Por otro lado, este derecho ha quedado enmarcado en el constitucionalismo multinivel, pudiendo entreverse las dificultades de integración e interpretación que suscita en el tejido multinivel.

Cuestiones como el diálogo entre tribunales, la distinta configuración del derecho de acceso según el ordenamiento en el que se interprete, el mayor estándar de protección del derecho en sede del CEDH, la falta de transparencia en los tiempos convulsos que enfrentamos, las eventuales vías para elevar el derecho a la categoría de fundamental en España o las consecuencias que tendría para el mismo la ratificación de la $\mathrm{UE}$ al $\mathrm{CEDH}^{76}$, revelan cuestiones claves del derecho en el constitucionalismo contemporáneo.

Así, garantizar este derecho en un contexto de crisis sanitaria, inserto a su vez en un marco de referencia multinivel, exige dar pasos en favor de la integración, de una mayor cohesión, de la democratización y unión política de la UE, así como la definitiva ratificación de la UE al CEDH. El camino trazado evitaría seguir creando incertidumbre en la protección de los derechos ${ }^{77}$, toda vez que se avanzaría hacia una «cultura común de los derechos» ${ }^{78}$ presidida por un lógica de cohesión y armonización. Este camino desde la perspectiva internacional de los derechos, debe a su vez

76 AZPITARTE SÁNCHEZ, M. (2015). «Los derechos fundamentales de la Unión: en busca de un nuevo equilibrio». Revista Española de Derecho Constitucional, $\mathrm{n}^{\circ} 104$, p. 268, advierte que con la mera adhesión de la UE al CEDH se entablaría un marco común en el proceso de integración, en el que las particularidades y autonomía de cada ordenamiento exigiría un control externo llevado a cabo por parte del CEDH y el TEDH.

77 En este sentido se pronunciaba el presidente del TEDH Dean Spielmann en la apertura del año judicial del TEDH de 2015, en la que puso de manifiesto a propósito de la no adhesión de la UE al $\mathrm{CEDH}$ que lo relevante no es la existencia de una concepción jerárquica entre sistemas en conflicto, sino que lo verdaderamente importante es asegurar la coherente garantía de los derechos fundamentales en Europa. President Dean Spielmann, Solemn hearing for the opening of the judicial year of the European Court of Human Rights. Opening speech, Estrasburgo, 30 de enero de 2015, p. 5. Disponible en https://www. echr.coe.int/Documents/Speech_20150130_Solemn_Hearing_2015_ENG.pdf

78 Cfr. MARTINÓN QUINTERO, R. (2016). «Los derechos humanos en la Unión Europea. En especial, el problema de la adhesión de la Unión al Convenio Europeo de Derechos Humanos». Revista de Derechos Fundamentales, no 28, p. 59. 
completarse con una definitiva consolidación de la transparencia en España. En este sentido, se hace necesario elevar este derecho a presupuesto democrático imprescindible en la lucha contra el fenómeno de la desinformación. Es necesario evitar que a la pandemia del virus se le sume la de la desinformación. Y para ello el derecho de acceso deberá consolidarse definitivamente en nuestro país, sin que baste cualquier forma. A tal efecto, la voluntad política y el adecuado encuadre para su constitucionalización serán claves en orden a la reconciliación de posturas entre la ciudadanía y el poder público.

\section{REFERENCIAS BIBLIOGRÁFICAS.}

ACCESS INFO. (2020). «Transparencia e integridad en la contratación pública. Garantizar la transparencia de la contratación de emergencia: Recomendaciones». Disponible en: https://transparencia.org.es/wp-content/uploads/2020/05/Transparencia-y-publicidad-activa-recomendaciones-COVID19.pdf

Access Info. «España: la Coalición Pro Acceso pide al Gobierno que garantice el derecho de acceso a la información durante la crisis de la Covid-19», (27 de abril de 2020). Disponible en: https://www.access-info.org/es/blog/2020/04/27/espana-acceso-informacion-covid19/

Aragón Reyes, M. (2020). «Hay que tomarse la Constitución enserio». El País, 10 de abril de 2020.

AzPitarte Sánchez, M. (2015). «Los derechos fundamentales de la Unión: en busca de un nuevo equilibrio». Revista Española de Derecho Constitucional, no 104.

Balaguer Callejón, F. (2004). «Niveles y técnicas internacionales e internas de realización de los derechos en Europa. Una perspectiva constitucional». Revista de Derecho Constitucional Europeo, $\mathrm{n}^{\circ} 1$.

- (2008). «Constitucionalismo multinivel y derechos fundamentales en la Unión Europea», en Estudios en Homenaje al profesor Gregorio Peces-Barba, Dykinson, vol. 2.

— (2010). «La contribución de Peter Häberle a la construcción del Derecho constitucional europeo». Revista de Derecho Constitucional Europeo, $\mathrm{n}^{\circ} 13$.

- (2020). «El fracaso de una narrativa insolidaria». El País, 13 de marzo de 2020.

Bernardo, A. (2020). «La transparencia sobre las pruebas diagnósticas del coronavirus avanza a varias velocidades». Civio. Disponible en https://civio.es/medicamentalia/2020/05/13/coronavirus-covid-19-pcr-pruebas-datos-transparencia/

Bilancia, P. (2006). «Las nuevas fronteras de la protección multinivel de los derechos». Revista de Derecho Constitucional Europeo, $\mathrm{n}^{\circ} 6$.

Blanes Climent, M. A. (2004). La transparencia informativa de las administraciones públicas. El derecho de las personas a saber y la obligación de difundir obligación pública de forma activa. Navarra, Thomson Reuters, Aranzadi. 
Blanes Climent, M. A. (2020). «Comentarios a la Nota del Portal de Transparencia (17/4/2020): se confirma el apagón informativo sobre el Covid-19 durante el estado de alarma». Blog de Transparencia y Gobierno Abierto - Transparency and Open Government.

Blanes Climent, M. A. (2020). «Tenemos derecho a saber quiénes son las personas expertas del Ministerio de Sanidad sobre el Covid-19 y a conocer sus informes». Blog de Transparencia y Gobierno Abierto - Transparency and Open Government.

Cascajo Castro, J. L. (2008). «Interpretación constitucional y constitucionalismo multinivel», en Ferrer MaC-Gregor, E., y Zaldívar Lelo De Larrea, A, (Coords.), La ciencia del Derecho Procesal Constitucional. Estudios en homenaje a Héctor Fix-Zamudio en sus cincuenta años como investigador del Derecho, México, UNAM, Vol. IV. Disponible en https://archivos.juridicas.unam.mx/www/bjv/ libros/6/2560/12.pdf

Costa-SÁnCHeZ, C y López-García, X. (2020). «Comunicación y crisis del coronavirus en España. Primeras lecciones». El profesional de la información, v.29, n³.

Cuenca Gómez, P. (2012). «La incidencia del Derecho Internacional de los derechos humanos en el Derecho Interno: la interpretación del art. 10.2 de la Constitución Española». Revista de Estudios Jurídicos, n ${ }^{\circ} 12$.

De La Nuez Cascado, E. (21 de abril de 2020). «Transparencia, libertad de información y Covid-19». El Español https://www.elespanol.com/invertia/opinion/20200421/ transparencia-libertad-informacion-covid-19/484071595_12.html

De La Quadra-Salcedo, T. (28 de abril de 2020) «La aversión europea al estado de excepción». El País. https://elpais.com/elpais/2020/04/27/opinion/1587997245_501599.html

Díaz Revorio, F. J. (9 de abril de 2020). «A vueltas con la suspensión de los derechos fundamentales». Almacén de Derecho. https://almacendederecho.org/a-vueltas-con-la-suspension-de-los-derechos-fundamentales

Fernández Rozas, J. C. (2014). «La compleja adhesión de la Unión Europea al Convenio Europeo de Derechos Humanos y las secuelas del Dictamen 2/2013 del Tribunal de Justicia». Revista La Ley Unión Europea, n ${ }^{\circ} 23$.

Gamero Casado, E. (11 de abril de 2020). «La contratación de emergencia ante el coronavirus no puede ser un 'cheque en blanco'». Vozpópuli.

- (2020). «Transparencia y contratación de emergencia ante el Covid-19». Observatorio de Contratación Pública.

García Roca, J. (2012). «El diálogo entre el Tribunal Europeo de Derechos Humanos y los Tribunales constitucionales en la construcción de un orden público europeo». Teoría y realidad constitucional, $\mathrm{n}^{\circ} 30$.

- (2018). «La transformación del Convenio europeo de derechos humanos». Revista General de Derecho Constitucional, $\mathrm{n}^{\circ} 18$.

Gimeno Feliú, J.M. (2020). «La crisis sanitaria covid-19 y su incidencia en la contratación pública». El Cronista del Estado Social y Democrático de Derecho, ejemplar dedicado a Coronavirus y otros problemas, $n^{\circ}$. 86-87. 
Gimeno Feliú, J.M. (2020). » La crisis sanitaria covid-19. Reflexiones sobre su incidencia en la contratación pública y las soluciones adoptadas». Jornada organizada por Regulation and Digital Innovation Research Group UV y Observatorio 155. Texto disponible en http://www.obcp.es/sites/default/files/2020-04/LA-CRISIS\%20SANITARIA $\%$ 20COVID-19.\%20REFL $\%$ 20EXIONES\%20SOBRE $\% 20$ SU\% 20 INCIDENCIA $\% 20$ EN\%20LA\%20CONTRATACIOi\%CC\%80N\%20PUi\%CC\%80BLICA\%20Y\%20LAS\%20SOLUCIONES\%20ADOPTADASv2.pdf

Gómez SÁnCHEZ, Y. (2018). Constitucionalismo multinivel. Derechos fundamentales, Madrid, Sanz y Torres, $4^{a}$ edición.

GonzÁlez Alonso, L. N. (2008). «Artículo 42. Derecho de acceso a los Documentos», en Mangas Martín, A. (Dir) y González Alonso, L.N (Coord). Carta de los Derechos Fundamentales de la Unión Europea. Comentario artículo por artículo. Madrid, Fundación BBVAA.

HäBERLE, P. (2004). «Europa como comunidad constitucional en desarrollo». Revista de Derecho Constitucional Europeo, $\mathrm{n}^{\circ} 1$.

- (2018). «El constitucionalismo como proyecto científico». Revista de Derecho Constitucional Europeo, $\mathrm{n}^{\circ} 29$.

Hermida, C. (2010). «Una salida a los conflictos entre el Tribunal de Estrasburgo y el Tribunal de Luxemburgo». Persona y Derecho, n 63.

Kleis Nielsen, R; Fletcher, R; Newman, N; Scott Brennen, J Y N. Howard, P. (2020). «Navigating the 'infodemic': how people in six countries access and rate news and information about coronavirus». Reuters Institute, University of Oxford. Disponible en https://reutersinstitute.politics.ox.ac.uk/infodemic-how-people-six-countries access and rate-news-and-information-about-coronavirus

- «La justicia tumba los comités opacos y los informes apócrifos como los del Gobierno». (10 de mayo de 2020). El Confidencial. https://www.elconfidencial. com/espana/2020-05-10/sentencias-comites-sanitarios-opacos-informes-firma_2587304/

— «La OCDE rectifica y baja a España del octavo puesto al decimoséptimo en número de test de coronavirus realizados». (28 de abril de 2020). El País. https:// elpais.com/sociedad/2020-04-28/la-ocde-admite-que-tendra-que-ajustar-las-cifras-de-los-test-de-espana-para-que-sean-comparables-con-el-resto.html

- «Los diferentes criterios con los que se recogen los datos impiden conocer la dimensión de la epidemia en España». Eldiario.es, 30 de marzo de 2020. https:// www.eldiario.es/sociedad/coronavirus-epidemia-datos_1_1221126.html

Martín Y Pérez Nanclares, J. (2015). «El TJUE pierde el rumbo en el Dictamen 2/13: ¿merece todavía la pena la adhesión de la UE al CEDH?». Revista de Derecho Comunitario Europeo, $\mathrm{n}^{\circ} 52$.

Martinón Quintero, R. (2016). «Los derechos humanos en la Unión Europea. En especial, el problema de la adhesión de la Unión al Convenio Europeo de Derechos Humanos». Revista de Derechos Fundamentales, $\mathrm{n}^{\circ} 28$. 
Monereo Pérez, J. L. (2016). «El constitucionalismo social europeo ante los nuevos poderes soberanos», en GARCÍA HERRERA, M.A, ASENSI SABATER, J, BALAGUER CALLEJÓN, F, et al. Constitucionalismo crítico: Liber amicorum Carlos de Cabo Martín, Tirant lo Blanch, vol. 1.

Montilla Martos, J. A. (2016). "Transparencia y acceso a la información en España», en SARLET, I. W; MONTILLA MARTOS, J.A; LINDEN RUARO, R (Coords.) Acesso à informaçao como direito fundamental e dever estatal. Porto Alegre, Livraria do Advogado Editora.

MuÑoz-Machado CAÑAs, J. (2020). «Noticias falsas. confianza y configuración de la opinión pública en los tiempos de internet». El Cronista del Estado Social y Democrático de Derecho, ejemplar dedicado a Coronavirus y otros problemas, $\mathrm{n}^{\circ}$. 86-87.

Ó Fathaigh, R y Voorhoof, D. (2020). «Refusal to give access to 'confidential' information about politicians violated NGO's Article 10 rights». Strasbourg Observers, 27 de abril de 2020. Disponible en https://strasbourgobservers. com/2020/04/27/refusal-to-give-access-to-confidential-information-about-politicians-violated-ngos-article-10-rights/

Ollero Tassara, A. (2018). «Diálogo de Tribunales en el marco europeo», en DE LUCAS MARTÍN, F. J; Vidal Gil, E. J y Fernández Ruiz-Gálvez, E (Coords.) Pensar el tiempo presente. Homenaje al profesor Jesús Ballesteros Llompart. Tirant lo Blanch, vol.1.

Pernice, I. (2015). «Multilevel Constitutionalism and the Crisis of Democracy in Europe». European Constitutional Law Review, n ${ }^{\circ} 11$.

Piñar Mañas, J. L. (2020). «Contra los bulos, transparencia. O sobre cómo la transparencia y el derecho a saber son exigencias democráticas también (o aún más) en estado de alarma». Hay Derecho, Expansión.

Presno Linera, M. (2020). «Coranavirus SARS-CoV-2 y derechos fundamentales (3): la emisión y recepción de información». Blog El derecho y el revés.

Rams Ramos, L. (2013). «La transformación del derecho de acceso en España: de derecho de configuración legal a derecho fundamental». Revista Española de Derecho Administrativo, $\mathrm{n}^{\circ} 160$.

Ripol Carulla, S. (2007). El sistema europeo de protección de los derechos humanos y el Derecho español. Barcelona, Atelier.

ROLLNERT Liern, G. (2014). «El derecho de acceso a la información pública como derecho fundamental: una valoración del debate doctrinal a propósito de la ley de transparencia». Teoría y Realidad Constitucional, $\mathrm{n}^{\circ} 34$.

Scarlatti, P. (2011). Democracia y teoría de la legitimación en la experiencia de la integración europea. Contribución a una crítica del constitucionalismo multinivel. Servicio editorial de la Universidad del País Vasco.

— «The Covid-19 pandemic has catapulted one mysterious data website to prominence, sowing confusion in international rankings». (19 de mayo de 2020). CNN. https:// edition.cnn.com/interactive/2020/05/world/worldometer-coronavirus-mystery/ 
— «Transparencia Internacional España. «Transparencia y publicidad activa: covid-19 y estado de alarma en España Recomendaciones para la transparencia y prevención de la corrupción en el sector público y privado». (mayo de 2020). Disponible en https://transparencia.org.es/wp-content/uploads/2020/05/Transparencia-y-publicidad-activa-recomendaciones-COVID19.pdf

— «Un grupo de juristas pide al Defensor del Pueblo que impugne el decreto del estado de alarma por ser «inconstitucional». (19 de abril de 2020). El Mundo. https://www.elmundo.es/espana/2020/04/19/5e9c8ecb21 efa0096a8b45c3.html

VAn DE Heyning, C y Lawson, R. (2011). "The EU as a party to the European Convention of Human Rights: EU law and the European Court of Justice case law as inspiration and challenge to the European Court of Human Rights jurisprudence», en POPELIER, P., VAN DE HEYNING, C., VAN NUFFEL, P (Eds.) Human rights protection in the European legal order: The interaction between the European and the national courts, Cambridge, Intersintia.

Yuval Noah Harari: «La mejor defensa contra los patógenos es la información». (22 de marzo). El País. https://elpais.com/cultura/2020-03-21/yuval-noah-harari-la-mejor-defensa-contra-los-patogenos-es-la-informacion.html

Title:

The right of access to public information within the framework of multilevel constitutionalism and the current health crisis.

\section{Summary:}

1. Introduction. 2.- An approach to the right of access to public information in the current context of the COVID-19 health crisis. 3.- Brief reference to multilevel constitutionalism in the current context. 4.- The right of access to public information within the framework of multilevel constitutionalism. 4.1.a.- The right of access to public information in the Council of Europe. 4.1.b.- The right of access to public information in the EU. 4.2.- Multilevel integration problems regarding the right of access to public information. 5.- Conclusions. 6.- References.

\section{Resumen:}

El objetivo de este trabajo se centra en conectar dos cuestiones claves del constitucionalismo contemporáneo. En concreto, se vincularán problemas 
derivados del constitucionalismo multinivel con el derecho de acceso a la información pública en contexto actual. Se ha visto que la teoría del constitucionalismo multinivel suscita aun problemas metodológicos de integración que pueden causar dificultades en la interpretación de los derechos fundamentales. Esa falta de integración se revela de manera clara en relación con aquellos derechos que están ajustando su alcance y contenido a la luz de la realidad social del momento, y que además cuentan con diverso grado o forma de protección en atención al espacio constitucional en que se estudien. Esta idea es la que justifica la elección del derecho de acceso a la información pública como vehículo para poner de manifiesto algunas cuestiones pendientes de integración en el sistema multinivel. De un lado, el derecho de acceso a la información pública ostenta una relevancia democrática que sin duda alguna se ha visto reforzada en el marco de la actual crisis sanitaria del COVID-19. Podrá comprobarse en este sentido el papel esencial que viene desarrollando el derecho de acceso a la información pública en la gestión nacional e internacional de la pandemia para compensar arbitrariedades, falta de transparencia, inseguridad jurídica y todas las incertidumbres generadas por la propagación de desinformación. A este papel democrático esencial se suma otro dato relevante y es que el análisis del derecho de acceso a la información pública adquiere interés constitucional por sí mismo. Se trata de un derecho sumamente rico, que aporta matices en lo relativo a la interpretación de los derechos, puesto que es objeto de diferente grado o forma de protección a tenor del espacio constitucional en el que se analice (Consejo de Europa, Unión europea y ordenamiento interno español). De manera que, un acercamiento al derecho de acceso a la información pública permitirá reflejar algunas cuestiones pendientes para la interpretación de los derechos en el contexto multinivel.

\begin{abstract}
:
The aim of this paper focuses on connecting two key subjects of contemporary constitutionalism. Specifically, problems arising from multilevel constitutionalism will be link with the right of access to public information in the current context. It has been seen that the theory of multilevel constitutionalism still raises integration methodological problems that could cause difficulties in the interpretation of fundamental rights. This lack of integration is clearly revealed in relation to those rights that are adjusting their scope and content in the light of the social reality of the moment, and which also have different degrees or forms of protection depending on the constitutional space in which they are studied. This is the reason which justifies the choice of right of access to public information as vehicle to highlight some of the issues pending integration into the multilevel system. On the one hand, the right of access to public information has a democratic relevance that has undoubtedly been reinforced in the framework of the current health crisis of the COVID-19. In this regard, it will be possible to verify the essential role that the right of access to public information has been playing in the national and
\end{abstract}


international management of the pandemic to compensate for arbitrariness, lack of transparency, legal insecurity and all the uncertainties generated by the spread of disinformation. To this essential democratic role is added another relevant fact, and it is that analysis of the right of access to public information acquires constitutional interest by itself. It is an extremely interesting right, which provides nuances regarding the interpretation of rights, because it is subject to a different degree or form of protection under the constitutional space in which it is analysed (Council of Europe, European Union or Spanish legal system). Thus, an approach to the right of access to public information will allow to reflect some pending questions for the interpretation of rights in the multilevel context.

\section{Palabras clave:}

constitucionalismo multinivel; derechos fundamentales; derecho de acceso a la información pública; COVID-19.

\section{Keywords:}

multilevel constitutionalism; fundamental rights; right of access to public information; COVID-19. 
